\title{
At-Turats
}

Jurnal Pemikiran Pendidikan Islam

journal homepage: http://jurnaliainpontianak.or.id/index.php/atturats

\section{WAJAH TAFSIR DALAM KARYA ILMIAH DOSEN PERGURUAN TINGGI KEAGAMAAN ISLAM SE-KALIMANTAN BARAT TAHUN 2014-2017}

\author{
SYARIF \\ IAIN Pontianak \\ Email: zsyarif99@yahoo.co.id
}

\begin{abstract}
ABSTRAK
Karya tulis dalam dunia akademis adalah ruh dari kesarjanaan. Sedangkan ruh dari tradisi kesarjanaan muslim adalah mengutip ayat-ayat al-Quran yang kemudian ditafsirkan. Hal tersebut telah lumrah dilakukan oleh para dosen di lingkungan perguruan tinggi Islam. Penelitian ini berupaya menggambarkan corak penafsiran yang dilakukan oleh para dosen di sejumlah karya ilmiahnya, baik dalam bentuk buku, jurnal maupun artikel. Dengan menggunakan telaah kepustakaan di sejumlah perguruan tinggi di provinsi Kalimantan Barat ditemukan bahwa corak tafsir yang digunakan oleh para dosen adalah Tafsir Maudhu'i. Sedangkan jika dilihat dari pola narasinya lebih banyak mendekati pada pola Tafsir Bil Ra'yi serta digunakan dalam keilmuan multidisipliner.
\end{abstract}

Keywords: Al-Quran, Tafsir

\section{PENDAHULUAN}

Al-Qur'an ${ }^{1}$ sebagai referensi pertama umat Islam merupakan wahyu yang diturunkan dengan mengandung beberapa tujuan, menurut Rasyi $>\mathrm{d}$ Rid\}a>, untuk menerangkan hakikat

\footnotetext{
${ }^{1}$ Salah satu ulama yang menyeru agar memahami al-Qur'an harus dengan alQur'an dan begitupun dalam menefinisikannya ialah Muhammad Abid alJabir, menurutnya, definisi al-Qur'an dapat dipahami dengan cara menggabungkan tiga ayat, yaitu: 1) Q.S. al-Syu'ara [26]: 192-196, Q.S. al-Isra' [17]: 106, dan Q.S. Ali Imran [3]: 3-4. Dengan menggabungkan tiga macam ayat tersebut, al-Jabiri sampai kepada sebuah kesimpulan bahwa yang dimaksud dengan al-Qur'an adalah wahyu yang diturunkan oleh Allah s.w.t. dengan dibawa
}

agama yang meliputi iman kepada Tuhan, iman kepada hari kebangkitan, amal soleh dan menjelaskan tentang kenabian dan kerasulan serta tugastugasnya. ${ }^{2}$ Berhubungan dengan fungsi dan tujuan al-Qur'an ini diturunkan, menurut Ghallab, al-Qur'an diturunkan

oleh Malaikat Jibril, wahyu yang membedakan mana yang hak dari yang batil, dan diturunkan sebagai pembenar dari informasi dari kitab Taurat dan Injil, serta untuk menjadi petunjuk bagi umat manusia. Lihat dalam, Muhammad Abid al-Jabiri, Madkhal Ila> al-Qur'a>n al-Kari>m (Beiru>t: Markaz Dira>sa>t al-Wah\}dat al'Arabiyyah, 2006), h. 19.

${ }^{2}$ Rasyi $>$ d Rid $\{\mathrm{a}>$, al-Wah $\}$ y al-

Muh\}ammadi> (al-Qa>hirah: Maktabat alQa>hirah, 1960, H.), h. 126. 


\section{At-Turats}

Jurnal Pemikiran Pendidikan Islam

journal homepage: http://jurnaliainpontianak.or.id/index.php/atturats

tidak hanya terbatas pada memberi pedoman dalam satu aspek kehidupan, melainkan juga mencakup kepada seruan agar manusia mempelajari, memahami dan menafsirkannya. ${ }^{3}$ Dengan adanya kemampuan menafsirkan al-Qur'an, diharapkan seseorang menemukan jalan keluar dalam menyelesaikan problembatika kehidupan melalui petunjuk-petunjuk yang termuat di dalamnya. Namun sebaliknya, al-Qur'an tidak bisa berfungsi sebagai petunjuk jika tidak dibaca dan dipelajari. Menarik dipahami dari pernyataan 'Ali> r.a. yang menyeru agar al-Qur'an diajak berbicara

\footnotetext{
${ }^{3}$ Abd Kari>m Ghallab, Si > rah al-Madza $>$ hib wa al- 'Aqa> 'id fi> al-Qur' $a>n$ (Beirut: Dar al-Kitab al-Lubnaniyah, t.th.), h. 11-12.

${ }^{4}$ Muh\{ ammad Ba>qir al-Sadar, al-Madrasat al-Qur'a>niyyah (T.t.p.: Marka $>\mathrm{z}$ Tah\} qi $>$ qat Kamfiyu $>$ ter 'Ulu $>$ m alIsla>mi>, t.th.), h. 22.

${ }^{5}$ Beberapa ulama yang corcern pada kajian Tafsir memiliki varian definisi, menurut alDzahabi, tafsir adalah istilah yang ditunjukkan kepada sebuah ilmu yang membahas maksud dari ayat-ayat Allah sesui kemampuan manusia. la mengandung pengetahuan yang dapat membawa kepada pemahaman makna dan penjelasan maksud dari firman Allah. Adapun sesuatu yang dapat membawa kepada pemahaman makna dan penjelasan maksud itu ialah semua pengetahuan penunjangnya seperti pengetahuan tentang IImu Qiraat, Tashrif, I'rab, ilmu Bayan dan Badi', IImu Hakikat dan Majaz, ilmu Naskh-Manshukh, dan Sabab alNuzul, dan lain sebagainya. Muhammad Husain al-Dzahabi>, al-Tafsi>r wa alMufassiru>n, (Kairo: Maktabah Wahbah, 2003), cet. 8, Jilid I, h. 13-14. Menurut alZarkasyi, ialah suatu ilmu yang mengantarkan pada pemahaman makna alQur’an dan penjelasan maksudnya lebih umum dari sekedar penjelasan lafazh yang musykil, dan dari sekedar penjelasan makna zhahir dan selainnya. Ilmu tersebut dalam istilah ilmu tafsir ialah ilmu kisah-kisahnya,
}

(z)a>lika al-Qur'a>n fa istantiqu>hu). Tentunya yang dimaksud adalah menafsirkannya, karena pada hakikatnya teks al-Qur'an merupakan kumpulan berita yang sifatnya bisu-pasif yang hanya menyediakan informasi, namun dengan mengkajinya akan lahir sikap interaksi-komunikasi yang aktif antara al-Qur'an dengan pembaca (baca: Mufassir). Al-Qur'an menjadi sebuah media yang akan menjawab semua pertanyaan-pertanyaan dari pembaca yang menafsirkannya. ${ }^{4}$

Kegiatan tafsir $^{5}$ merupakan bentuk sikap ikhtiyar seseorang untuk

isyarat turunnya, urutan Makkiyah Madani, Muh\}kam Mutasya>bih, Na>sikhMansu>kh, Khasl-'Am, dan MuthlaqMuqayyad, serta Mujmmal-Mufas \s\hal. Baca: Badr al-Di>n Muh\{ammad bin 'Abd Alla $>$ h al-Zarkasyi>, al-Burha $>n$ fi> 'Ulu>m al-Qur'a>n, (Kairo: Da>r alHadi>ts, 2006), h. 416-417. Sedikit agak berbeda dengan pendapat di atas, menurut al-Zarqa >ni> mengemukakan tiga definisi. Perama,bahwa tafsir dalam pengertian istilah adalah ilmu yang di dalamnya dibahas hal ihwal al-Qur'an dari segi dalalahnya untuk memahami maksud Allah sesuai kemampuan manusia. Kedua, tafsir adalah suatu ilmu yang mengkaji hal-ihwal Kitab dari segi Sabab Nuzulnya, Sanad, cara bacanya, lafazh-lafazh, dan hukum-hukumnya. Ketiga, tafsir adalah suatu ilmu yang mengkaji tentang cara penuturan lafazh-lafazh alQur`an, petunjuk-petunjuknya, hukumhukumnya baik yang berdiri sendiri maupun yang berangkai susun dengan yang lainnya, makna-makna lain yang dikandungnya, dan hal lain seperti tentang Naskh-Mansukh, Sabab al-Nuzul, dan aspek-aspek yang dapat membantu menjelaskan seperti Kisah dan Amtsal (perumpamaan). Menurutnya, yang pertama di atas yang lebih mudah dan simpel. Muh\}ammad 'Abd al-'Azhi>m alZarqa $>$ ni>, Mana > hil al-'Irfa $>n f i>$ 'Ulu>m al-Qura $>n$, (Kairo: Da>r al-Hadi>ts, 2001), Jilid II, h. 7. Bandingkan Muh\{ammad 


\section{At-Turats}

Jurnal Pemikiran Pendidikan Islam

journal homepage: http://jurnaliainpontianak.or.id/index.php/atturats

mendekati makna yang sesungguhnya dari fakta teks dalam kitab al-Qur'an. Artinya tafsir merupakan bagian yang tidak bisa dipisah dari teks-teks alQur'an. Sementara teks al-Qur'an merupakan represntasi pedoman untuk mendapatkan kebenaran. Tentunya yang harus merasa butuh pada tafsir ini adalah orang-orang yang mempercayai alQur'an, yaitu orang-orang Islam dan Indonesia merupakan negara yang penduduknya mayoritas beranut agama Islam. Patutnya mereka memfondasikan diri dengan al-Qur'an sebelum menekuni ilmu-ilmu yang lain.

Oleh karena itu, Indonesia menyediakan pendidikan formal sebagai wadah dan sarana dari representasi pembelajaran atas teks al-Qur'an, yaitu Perguruan Tinggi yang basisnya adalah ilmu ke-Islam-an. Secara umum, Perguruan Tinggi Islam mengemban amanah untuk menciptakan masyarakat akademik yang cakap ilmu dan menjadi

$\mathrm{H}\{$ usain al-Z|ahabi>, Buh\}u>tsun fi> 'Ulu>m al-Tafsi>r wa al-Fiqh wa alDa'wah, (Kairo: Da>r al-Hadi>ts, 2005), h. 385. Al-Ashfaha>ni> membedakan tafsir dari ta'wil, bahwa tafsir lebih umum dari ta'wil, lebih sering digunakan dalam menjelaskan lafazh-lafazf, sedangkan ta'wil lebih sering digunakan dalam menjelaskan makna seperti ta'wil mimpi yang banyak digunakan dalam kitab-kitab ketuhanan dan tafsir di dalam kitab-kitan lain, juga tafsir lebih banyak digunakan dalam menjelaskan makna-makna kosakata lafazh. Al-Ragi $>\mathrm{b}$ al-Ashfa>hani>, al-Mufrada>t fi> Gari $>b$ al-Qur`a>n (Beirut: Da>r al-Ma'rifah, t.th.), h. 99-100. Sementara tujuan dan fungsi tafsir dapat disebut bahwa ia untuk menjadikan teks al-Qur`an, sebagai objek awalnya dengan memberikan perhatian penuh pada teks tersebut, agar jelas maknanya. Selain itu, ia juga berfungsi secara simultan mengadaptasikan teks pada situasi yang sedang dihadapi mufassir. Dengan kata lain, agen perubahan sosial (agen of social change) sesuai dengan tuntutan agama Islam. Sebagaimana Perguruan Tinggi pada umumya, Perguruan Tinggi Islam juga mengembangkan budaya akademik yang berpangkal pada Tridharma Perguruan Tinggi, yakni: 1) pendidikan, 2) penelitian, dan 3) pengabdian kepada masyarakat. ${ }^{6} \quad$ Perguruan Tinggi Keagamaan Islam dalam hal ini para dosen-dosennya adalah ujung tombak pengemban amanah tersebut.

Nilai-nilai inilah yang akhirnya membedakan masyarakat akademik di kampus dengan masyarakat akademi pada pendidikan menengah dan tingkat di bawahnya. Kekhasan Perguruan Tinggi dibanding dengan tingkat satuan pendidikan sebelumnya, macakup banyak aspek sosial, aspek pembelajaran, aspek kompetensi dan aspek kepribadian. Aspek-aspek tersebut menjadi inspirasi terwujudnya sebuah masyarakat akademi dengan nalar keilmuan yang lebih

kebanyakan penafsiran tidaklah murni teoritis, ia mempunyai aspek praktis untuk membuat teks dapat diterapkan dalam memantapkan keimanan dan menjadi pandangan hidup orang mukmin. Demikian dicatat dalam: Andrew Rippin, "Tafsir", dalam Mircea Eliada (ed.), The Encyclopedia of Religion, (New York: Simon \& Schuster Macmillan, 1995), vol. XIII, h. 239.

Sebagai catatan tambahan, tafsir tidak harus memuat interpretasi 30 juz al-Qur'an dari seluruh ayat dan surahnya, melainka menyelipkan satu ayat saja dan menafsirkannya sudah masuk dalam kategori tafsir. Oleh karena itu, muatan tafsir-jika memang ada-dalam karyakarya ilmiah dosen di Perguruan Tinggi Keagamaan Islam se-Kalimantan Barat tidak berarti harus lengkap menafsirkan seluruh al-Qur'an.

${ }^{6}$ Keterangan tentang Tridharma bagi dosen ini sebagaimana tercantum di dalam UU No. 12 Tahun 2012, Pasal 1 Ayat 9. 


\section{At-Turats}

Jurnal Pemikiran Pendidikan Islam

journal homepage: http://jurnaliainpontianak.or.id/index.php/atturats

dewasa di perguruan tinggi. Bagian yang sangat penting dari fungsi para dosen tersebut di atas, adalah karya-karya ilmiah mereka. Kaitannya dengan tafsir, para dosen pengampu amanah tersebut di atas semestinya dapat mengadaptasikan karya-karya mereka dengan tafsir secara proforsional.

Kalimantan Barat adalah salah satu provinsi di Kalimantan yang memiliki Perguruan Tinggi Islam yang relatif banyak $^{7}$ dan dosen-dosennya sudah banyak melahirkan karya-karya ilmiah. Menelisik Tridharma Perguruan Tinggi yang kedua di atas tersebut, penelitian, banyak dari kalangan dosendosen yang produktif dalam melahirkan kaya-karya penelitian. Menguak muatan nilai-nilai tafsir pada produktifitas ilmiah dosen di kalimantan Barat tersebut dipandang memiliki arti yang cukup sifnifikan, sehingga perlu dilakukan penelitian. Survey awal peneliti menengarai bahwa dalam karya-karya dosen di Perguruan Tinggi Keagamaan Islam di Kalimantan Barat minim muatan tafsir.

Menilik pentingnya tafsir dalam memahami teks al-Qur'an, dan pentingnya fungsi dosen Perguruan Tinggi Keagamaan Islam dalam mengemban amanah seperti yang diuraikan di atas, serta memperhatikan fakta sebagai hasil survey awal peneliti, maka peneliti tertarik untuk mengadakan penelitian lebih dalam tentang

${ }^{7}$ Misalnya, Institut Agama Islam Negeri (IAIN) Pontianak, Universitas Muhammadiyah Pontianak, Sekolah Tinggi Ilmu Syariah (STIS) Syarif Abdurrahman Pontianak, Sekolah Tinggi Agama Islam Negeri (STAI) Mempawah, Sekolah Tinggi Agama Islam (STAI) Al Haudh Ketapan, Sekolah Tinggi Ilmu Tarbiyah (STIT) Iqro Putussibau, Sekolah
"Bagaimana muatan tafsir dalam bukubuku ber-ISBN dan artikel di jurnal terakreditasi para dosen di Perguruan Tinggi Keagamaan Islam se-Kalimantan Barat".

Dari sejumlah argumen di atas maka dapat dirumuskan sejumlah pokok persoalan sebagai berikut :

Pertama, bagaimana cara dosen Perguruan Tinggi Keagamaan Islam seKalimantan Barat memuatkan tafsir pada buku-buku ber-ISBN dan artikel di jurnal terakreditasi para dosen di Perguruan Tinggi Keagamaan Islam se-Kalimantan Barat?

Kedua, corak tafsir apa saja yang termuat dalam buku-buku ber-ISBN dan artikel di jurnal terakreditasi para dosen di Perguruan Tinggi Keagamaan Islam se-Kalimantan Barat?

Ketiga, dalam hal apa saja tafsir dimuat dalam buku-buku ber-ISBN dan artikel di jurnal terakreditasi para dosen di Perguruan Tinggi Keagamaan Islam se-Kalimantan Barat?

\section{A. Metode dan Pendekatan \\ Penelitian}

Bentuk atau jenis penelitian yang penyusun gunakan dalam penelitian ini adalah penelitian kepustakaan (library research). Library research yaitu jenis penelitian yang dilakukan dengan tujuan untuk memperoleh data melalui penelusuran kepustakaan yang selanjutnya digunakan sebagai landasan

Tinggi Ilmu Tarbiyah (STIT) Syarif Abdurrahman Singkawang, dan bahkan kampus Umum seperti Universitas Tanjungpura membuka prodi Ekonomi Syariah, yaitu prodi yang fokus kajiannya terkait pengelolahan SDM (Sumber Daya Manusia) berdasarkan tuntutan syariah Islam; al-Qur'an dan Hadis. 


\section{At-Turats}

Jurnal Pemikiran Pendidikan Islam

journal homepage: http://jurnaliainpontianak.or.id/index.php/atturats

teoritis yang berkaitan dengan masalah yang penyusun teliti.

Jenis penelitian kepustakaan adalah suatu kegiatan penelitian yang hanya membatasi diri kepada pembacaan dan pengelolahan bahan penelitian yang sifatnya lebih kepada data-data kepustakaan, dan bukan berdasarkan wawancara atau angket kepada responden sebagaimana dalam penelitian lapangan. ${ }^{8}$

Adapun sumber pengumpulan data yang diperlukan dalam penelitian pustaka (library research) ini adalah data hasil pembacaan secara kritis terhadap karya-karya ilmiah dosen yang berbentuk buku ber-ISBN dan Artikel di Jurnal Perguruan Tinggi Keagamaan Islam di Kalimantan Barat.

Sedangkan pendekatan yang digunakan oleh peneliti dalam penelitian ini adalah pendekatan tekstual. Pendekatan tekstual yaitu sebuah pendekatan yang mengacu pada teks-teks yang terdapat dalam tulisan karya ilmiah para dosen di Perguruan Tinggi Keagamaan Islam di Kalimantan Barat dalam menafsirkan al-Quran dan dimuat di buku ber-ISBN dan Artikel di Jurnal. Tujuan dari pendekatan ini adalah untuk mendapatkan akurasi dalam analisa dan menjauhkan peneliti dari kesalahan interpretasi sehingga diperoleh kualitas analisa secara holistik. ${ }^{9}$

\section{B. Tafsir dalam Karya Ilmiah \\ Dosen}

1. IAIN Pontianak

Pertama, Manajemen Dakwah Masjid

Berbasis Keseteraan Gender Cucu

${ }^{8}$ IKAPI DKI Jaya, Metode Penelitian Kepustakaan (Jakarta: Yayasan Obor Indonesia, 2008), cet. II, h.1-3.
Nurjamilah. Berbicara. Berbicara dua hal yaitu dakwah dan gender. Secara umum laki-laki dan perempuan memiliki peran yang sama pada dua aspek tersebut.

Terdapat sejumlah kutipan ayat yang kemudian ditafisrkan oleh penulisnya. Pertama ayat-ayat yang berkenaan dengan manajemen yaitu yaitu: Q.S., Shad [27]: 27, Q.S. alAnfal [8]: 60, dan Q.S. al-Hasyr [59]: 18. Kedua ayat yang berkaitan dengan femenisme, dimana penulis buku ini berpendapat bahwa wanita dalam Islam memiliki fungsi fundamental dengan adanya nama surah yang disebut dengan surah an-Nisa. Kemudian yang ketiga adalah ayatayat yang berkaitan dengan manajemen masjid, yaitu Q.S. alTaubah [9]: 18.

Kedua, Komunikasi Islam ditulis oleh Harjani Hefni. Buku ini memuat tentang penjelasan komunikasi berdasarkan pandangan Islam. Herni menjelaskan bahwa kita perlu memahami komunikasi yang baik, karena tidak sedikit hanya karena gara-gara salah dalam

${ }^{9}$ Imam Gunawan, Metode Penelitian Kualitatif: Teori dan Praktik (Jakarta: Bumi Aksara, 2013), h. 82. 


\section{At-Turats}

Jurnal Pemikiran Pendidikan Islam

journal homepage: http://jurnaliainpontianak.or.id/index.php/atturats

berkomunikasi tersebarlah macammacam fitnah yang tidak terbendungkan, suami istri bercerai, dan lain-lain.

Muatan tafsir dalam buku ini menjelaskan tentang istilah komunikasi yang disampaikan oleh al-Quran. Istilah komunikasi yang pertama berkaiatan dengan komunikasi verbal ada tiga pertama lafadz dalam Q.S. Qaf [50]: 18, kedua qaul dalam ayat Q.S. al-An'am [6]: 93 dan ketiga qaulun ma'ruf dalam Q.S. al-Baqarah [2]: 235.

Metode yang digunakan oleh Hefni dalam hal ini menggunakan metode tematik kosa kata (al-tafsir maudu al-lafdzi. Walau kemudian juga tidak terlalu rinci, sehingga dengan demikian makna yang didapat juga tidak terlalu luas.

Ketiga, Psikologi Dakwah ditulis oleh Santa Rusmalita. Buku ini menyampaikaan esensi dakwah yang tidak sekedar luapan verbal, akan tetapi luapan ungkapan yang bertujuan mempengaruhi jiwa para jamaah. Untuk itu, maka seorang penceramah tidak hanya dituntut menguasai ilmu agama, akan tetapi juga harus memahmi psikologi audiennya.

Dalam buku ini kutipan ayat alQuran yang kemudian ditafsirkan oleh penulisnya adalah ayat yang berkaitan dengan jiwa seperti kata taku dalam Q.S. al-Bayyinah [98]: 78 dan kata huzn dalam Q.S. alQashash [28]: 13 dan Q.S. Thaha [20]: 40, marah dalam Q.S. alTawbah [9]: 123, benci dan cinta dalam Q.S. Ali Imran [3]: 31. Corak tafsir dalam buku ini dapat dibilang serupa dengan buku sebelumnya.

Keempat, Paradigma Akutansi Syariah ditulis oleh Nurmasari. Pada intinya buku ini berbicara bahwa agama itu persoalan akhirat akan tetapi juga menyankut persoalan dunia. Salah satu hal secara kasat mata adalah perbuatan duniawi namun juga bermakna ukhrawi terdapat pada perintah untuk berzakat. Berkaitan dengan argumentasi tersebut, penulis buku ini Q.S. alHujurat [39]: 13.

Secara kesleuruhan melihat metode yang digunakan oleh penulis 


\section{At-Turats}

Jurnal Pemikiran Pendidikan Islam

journal homepage: http://jurnaliainpontianak.or.id/index.php/atturats

buku ini adalah memaparkan ayat kemudian diperkuat dengan ayat yang lain. Corak ini sedikit berbeda dengan corak sebelumnya.

Kelima, Api dalam Islam; Konstruksi Pendidikan Damai dalam Pandangan al-Qur'an, ditulis oleh Eka Hendry. Inti dari buku ini adalah memparkan sisi perdamaian dalam Islam. Adapun corak penafsiran yang digunakan oleh penulis buku ini adalah metode kritik bahasa.

Dalam hal ini, ia menggunakan teori Konstruksi dari Richard Bell yang berpendapat bahwa bahasa alQur'an bukan hanya sekumpulan kosa kata, tetapi merupakan kumpulan dari sistem relasi. ${ }^{10}$ Ayatayat al-Qur'an yang dikaji ialah yang berkaitan dengan makna perang, seperti al-qita $>l, a l-h\} a r b, a l-i r h a>b$, al-jiha $>d,{ }^{11}$ dan dicari makna relasinya dengan ayat-ayat al-Qur'an yang bernada perdamaian, misalnya seperti silm, aslama, salim, salam, istaslama, muslim, dan men. ${ }^{12}$ Dari term-term tersebut, Hendry mememperkaya dengan ayat-ayat al-

\footnotetext{
${ }^{10}$ Eka Hendry, Api Damai Islam..., h. 29.
}

${ }^{11}$ Eka Hendry, Api Damai Islam..., h. 52.
Qur'an yang lain yang masih memiliki pembahasan sama, misalnya kata al-sulh\}u,al-wast\}l, al- 'afw, dan lain-lain.

Hendry mengemukakan tahapantahapan Tafsir Tematik dengan bebrapa cara, yaitu. Pertama, menentukan tema. Kedua, mencari ayat-ayat al-Qur' an yang membicarakan tentang tema baik secara langsung maupun tidak. Ketiga, dari ayat-ayat al-Qur'an tersebut dicari konteks historis turunnya. Keempat, setelah ayat-ayat tersebut terkumpul Hendry berupaya menempatkan ayatayat tersebut sesuai dengan masa turunnya, konsep Makki dan Madani. Kelima, ayat-ayat al-Qur'an yang terdiri dari berbagai surah itu dicari nilai-nilai keserasiannya (al-muna $>$ sabah). Keenam, kemudian pembahasanpembahasannya disususi sedemikian rupa hingga tersusun rapi. Ketujuh, terkadang penjelasan-penjelasan tersebut diperkuat dengan hadis atau riwayat sahabat yang dirasa cocok. Kedelapan, dicari ayat-ayat al-Qur'an yang nada maknanya khusus dan umum sehingga ditemukan titik temunya. ${ }^{13}$

Kesimpulan dari penelitian Hendry ini ialah bahwa perdamaian dalam al-Qur'an ialah ketundukan dan

\footnotetext{
${ }^{12}$ Eka Hendry, Api Damai Islam..., h. 37.

${ }^{13}$ Eka Hendry, Api Damai Islam..., h. 35.
} 


\section{At-Turats}

Jurnal Pemikiran Pendidikan Islam

journal homepage: http://jurnaliainpontianak.or.id/index.php/atturats

kepatuhan kepada Allah swt. Dalam pandangan al-Qur'an, hanya orang-orang yang telah mencapai kedamaian dalam dirinya yang akan menyebarkan perdamaian kepada orang lain. Istilah aljiha $>d$ khususnya di dalam al-Qur'an tidak bisa diartikan dengan satu wajah saja, karena terkadang bermakna bersungguh-sungguh yang dilakukan oleh seorang hamba dalam menjalani perintah-perintah-Nya. Sedangkan dalam menyelesaikan perselisihan terkadang alQur'an menggunakan cara personal, domestik, mua'malah, dan lain-lain. ${ }^{14}$

Langkat al-Tafsi $>r$ alMawd $\}$ $>$ ' $i>y$ di atas sesuai dengan yang diberikan oleh 'Abd al-H\{ayy alFarma>wi dalam kitab al-Bida $>$ yah Fi> al-Tafsi $>$ r al-Mawd $u>{ }^{\prime} i>\mathrm{y}$. Tulisan ini bisa masuk dalam kategori al-Tafsi $>r$ alMawd $\}$ u ' $i>y$ bahkan di dalamnya mengandung interdisipliner ilmu sehingga kajian tafsir yang ada di dalamnya kaya dengan informasi. Kajian tematik di sini lebih menitik beratkan kepada kajian kosa kata yang berhubungan dengan pendidikan perdamaian dalam al-Qur'an.

2. Institut Agama Islam Sultan Mahmud Syafiuddin (IAIS) Sambas

Pertama, Kholifa (Khilafah) dalam Al-Quran, ditulis oleh Sri Harjanti. Dalam pembahasannya, Harjanti mengawali dengan pembahasan tentang definisi khali>fah berdasarkan pandangan para ulama tafsir. Di antara beberapa referensi yang dikutip, ada pendapat Ibn Katsir yang turut menghiasi. Menurutnya kata khali>fah memiliki dua makna. Pertama, bermakna pengganti, yaitu amanah Allah kepada manusia untuk mengganti menjagakan kemakmuran hidup di muka bumi. Kedua, setiap manusia adalah pemimpin untuk dirinya dan kepada orang lain untuk memakmurkan kehidupan.

Pada karya Harjanti ditemukan beberapa point penting. Pertama, hakikatnya tulisanya ini mengkaji tigak ayat yang di dalamnya terdapat dua kata khali>fah dan satu yatakhlifu. Masuk dalam kategori penafsiran kosa kata ayat. Kedua, tidak ada penjelasan dari Harjanti terkait tiga ayat tersebut mana yang termasuk ayat Makki dan Madaniyyah. Padahal menentukan Makki dan Madani sangat berpengaruh dalam menentukan makna suatu ayat. Ketiga, tulisan ini tidak mencoba melakukan pencarian korelasi atau keseraian (al-muna $>$ sabah) antara ayat dengan ayat yang lain sehingga tidak terkuak sisi keserasian makna dari tiga ayat itu. Keempat, tidak ada keterangan secara spesifik terkait pemilihan tiga ayat, padahal ayat alQur'an yang menyebutkan kata khali>fah dan berbagai derivasinya

\footnotetext{
${ }^{14}$ Eka Hendry, Api Damai Islam..., h. 129.
} 


\section{At-Turats}

Jurnal Pemikiran Pendidikan Islam

journal homepage: http://jurnaliainpontianak.or.id/index.php/atturats

banyak sehingga penafsiran tematik ini tidak bisa disebut sebagai pandangan alQur'an lengkap.

\section{Kedua, Ekonomi Islam} Sebagai Sistem Mengatasi Kemiskinan di Indonesia, ditulis oleh Budi Iswanto. Muatan tafsir tulisan Budi Iswanto ini, penulis bisa katakan model tulisan ini masuk dalam kategori Tafsir Tematik (al-Tafsi $>r$ $a l-M a w d u>$ ' $i>y)$.

Sebab didahulukannya memilih tema lalu dicarikan ayat-ayat al-Qur'an yang penjelasannya mengarah kepada tema terpilih tersebut. Lalu ayat-ayat itu dicari tafsiran-tafsirannya. Kritikannya, tulisan ini terksan mengabaikan konteks sosio turunnya al-Qur'an. Tulisan ini lebih terfokuskan kepada kajian maknamakna lafaz dan terkesan meninggalkan makna di balik teksnya.

Ketiga, Manajemen Stress Melalui Bimbingan Konseling Islam, ditulis oleh Yusrain. Tulisan Yusrain ini bisa dikatakan tafsir, karena telah melakukan penjelasan-penjelasan terkait ayat al-Qur'an yang dikutipnya. Ayat-ayat al-Qur'an itu dipilih sengaja untuk menjelaskan sub-sub tema pembahasan. Terlihat dari tulisannya ini bahwa Yusrain terlebih dahulu mencari tema dan ayat al-Qur'an sebagai penjelasannya. Apabila dilihat dari kajian tafsirnya terletak pada kurangnya hadis-hadis sebagai penjelasan tambahan dan tidak adanya ilmu-ilmu al-Qur'an memperkuat penjelasan tafsirannya, misalnya seperti konteks historis ayat ( $s a b a b$ al-nuzu>l), keserasian ayat (al-muna>sabah), dan lain-lain.

\section{Sekolah Tinggi Agama Islam (STAI) Mempawah}

Pertama, Titik Temu Antara Hukum Islam dan Hukum Positif, ditulis oleh Miskari. Kata syari'at dalam buku ini disebutkan memiliki konotasi yang menunjukkan kepada arti hukum-hukum Allah swt yang dituangkan di dalam agama Islam. Dalam membicarakan definisi syari'ah, Miskari mengutip pendapat Yusuf Musa bahwa syariah merupakan semua aturan-aturan agama Islam. Untuk memperkokoh kutipan tersebut, Miskari mempertegaskannya dengan pernyataan ayat Q.S. al-Nisa' [4]: 59, yang artinya: "Hai orang-orang yang beriman, taatilah Allah dan taatilah Rasul (Nya), dan Ulil Amri di antara kamu..."

Menurut penulis, ayat al-Qur'an yang dikutip oleh Miskari tersebut kurang tepat untuk dijadikan sebagai penjelasan tentang definisi syariah. Padahal kalau ditelusuri dengan cermat ada penggunaan kata syariah dalam al- 


\section{At-Turats}

Jurnal Pemikiran Pendidikan Islam

journal homepage: http://jurnaliainpontianak.or.id/index.php/atturats

Qur'an yang maknanya mengarah kepada aturan-aturan Agama. Misalnya seperti dalam ayat Q.S. al-Ma'idah [5]: 48. Disinilah seharusnya Miskari mengutip pendapat Imam al-Qurtubi karena di dalam penafsirannya terdapat definisi dari syariah, sebagaimana berikut:

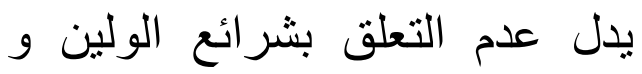

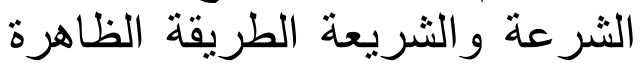

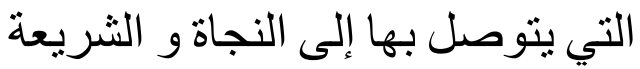
في اللغة الطريق الذي يتوصل ئوصل منه

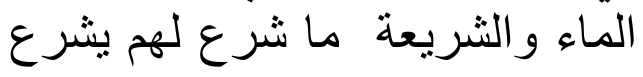
شـر عاء

(Ayat ini) menunjukkan (bahwa Islam) tidak ada bergantung dengan syariat-syarat orang terdahulu. Lafaz Syir'ah dan Syari'ah ialah jalan yang jelas yang dapat menyampaikan kepada kesuksesan. Lafaz Syari'ah dalam bahasa ialah jalan yang dapat menyampaikan kepada air, maka Syari'ah adalah sesuatu ketetapan yang ditetapkan untuk mereka sebagai hukum.

Dengan demikian, ayat Q.S. al-Nisa' [4]: 59 tidak bisa mewakili sebagai ayat yang menjelaskan tentang definisi syari'at, meski kandungan makna di dalamnya sedang membicarakan prihal suatu ketaatan kepada Allah swt, RasulNya, dan Ulil Amri yang merupakan

${ }^{15}$ Lihat dalam penafsiran, Ibn Kas $\} \mathrm{i}>\mathrm{r}$ Tafsi $>r$ al-Qur'a>n al-'Az $\backslash i>m \ldots . .$, juz. 8, h.38. bagian dari praktik syariah atau hukum-Nya.

Muatan tafsir lainnya, ketika Miskari menjelaskan tentang misi mulia dari hukum Islam. Miskari mengutip sebuah ayat yang menjelaskan tentang tujuan daripada syariah Islam ialah rahmat bagi seluruh alam semesta. Ayat al-Qur'an yang dimaksud sebagaimana dalam Q.S. Yunus [10]: 57 dan Q.S. alAnbiya' [21]: 107. Tidak ada syariat Islam kecuali untuk kemaslahatan manusia yang tidak didasarkan oleh hawa nafsu. Lebih spesifik lagi, syariat agama Islam hendak menjaga lima macam perkara, menjaga Agama, memelihara jiwa, memelihara akal, dan memelihara keturunan.

Kesimpulannya, berdasarkan pembacaan penulis, ditemukan hanya dua ayat al-Qur'an yang dikutip oleh Miskari, dan sangat singkat dalam penjelasannya. Dengan demikian, muatan tafsir dalam karya ini hanya bersifat penjelasan global saja, tidak 


\section{At-Turats}

Jurnal Pemikiran Pendidikan Islam

journal homepage: http://jurnaliainpontianak.or.id/index.php/atturats

ada di dalamnya mengenai kutipan

kepada ulama-ulama tafsir dan tidak

pula ada ilmu-ilmu tafsirannya.

Kedua, Pendidikan Karakter Perspektif al-Qur'an dan Hadis, ditulis oleh Guntur Cahyono. Guntur mengutip sebuah ayat Q.S. al-Ahzab [33]: 21 yang artinya: "Sesungguhnya telah ada pada (diri) Rasulullah itu suri teladan yang baik bagimu (yaitu) bagi orang yang mengharap (rahmat) Allah dan (kedatangan) hari kiamat dan Dia banyak menyebut Allah." Dengan adanya ayat ini, Guntur menafsirkan bahwa pendidikan karakter pada hakikatnya sudah digalakkan sejak pertama alQur'an itu diturunkan. Kemuliaan budi pekerti Nabi Muhammad saw tidak hanya untuk umat Islam tetapi juga untuk seluruh alam semesta. Berdasarkan hal itu tidak ada yang lebih pantas untuk ditiru dan teladani di dunia ini selain hanya Nabi Muhammad saw yang mendapatkan legalitas dari al-Qur'an.

Ajaran-ajaran yang mengandung nilai pendidikan karakter dalam alQur'an diungkapkan dengan banyak derivasi kalimat. Terkadang dengan ungkapan berbuat baik (al-ihlsa>n), kebajikan (al-birr), menempati janji (alwafa), jujur, dan lain sebagainya.

Beberapa ayat al-Qur'an yang menunjukkan kedudukan pendidikan karakter, di antaranya sebagaimana berikut: Pertama, ayat Q.S. al-Nahl [16]: 90. Ayat ini memerintahkan kepada umat manusia untuk berlaku adil, berbuat kasih sayang pada ciptaan-Nya dengan bersilaturrahmi pada mereka serta menjauhkan diri dari berbagai perbuatanperbuatan buruk yang dapat menyakiti dan merugikan orang lain.
Kedua, ayat Q.S. al-Isra' [17]: 23-24. Petunjuk yang diberikan oleh ayat tersebut adalah tentang pendidikan karakter dalam lingkungan keluarga yang mencakupi tentang akidah, ibadah, akhlak yang harus ditanamkan pada anak. Dengan demikian semakin jelas betapa al-Qur'an sangat mementingkannya sebuah akhlak. Berilmu tetapi tidak berakhlak akan sia-sia, ilmunya karena puncak daripada ilmu itu adalah akhlaknya.

Tulisan Guntur ini hakikatnya bukan tentang tafsir dalam arti khusus. Maksudnya penafsiran al-Qur'an yang berdasarkan metode-metode tafsir atau ilmu-ilmu tafsir. Adapun jika dilihat dari arti umumnya, disebut tafsir karena ada beberapa kutipan ayat al-Qur'an disertakan dengan penjelasan-penjelasan umum di dalamnya. Sehingga untuk dikatakan kajian tafsir masih belum mencukupi syarat sebagaimana dalam disiplin ilmu-ilmu al-Qur'an.

4. Sekolah Tinggi Agama Islam (STAI) AlHaudl, Ketapang, Kalimantan Barat

Pertama, Pendidikan Akhlak dalam Perspektif al-Qur'an (Telaah Tafsir Al-Misbah Surah al-Furqan [25]: 63-75), ditulis oleh Mutmainnah. Mutmainnah menjadikan Tafsir alMisbah, Karya dari Quraish Shihab, sebagai objek formalnya dan ayat Q.S. al-Furqan [25]: 63-75 sebagai objek material. Penelitian ini termasuk dalam kategori penelitian tokoh, karena Mutmainnah menjadikan pemikiran-permikiran 


\section{At-Turats}

Jurnal Pemikiran Pendidikan Islam

journal homepage: http://jurnaliainpontianak.or.id/index.php/atturats

interpretasi Quraish Shihab yang tertuang dalam Tafsir al-Misbah pada ayat tersebut sebagai alat untuk menganalisa objek material, yaitu kenakalan pada anak-anak sekolah yang acap kali membuat keributan, tawuran, dan saling menyerang antar anak sekolah.

Untuk menyelesaikan permasalahan pertikaian antar anak didik yang sedang marak itu, diperlukan adanya kerjasama antara para orang tua, guru dan masyarakat disekitar menanamkan pendidikan qurani kepada karakter anak didik yang paling tidak ada eman kriteria, yaitu: (1) Tawad)u' (Rendah Diri), (2) al-'Afwu (Memaafkan), $S \backslash \mid a h\} i>h \quad$ al-'Iba>dah (Baiknya Ibadah), (4) al-Istiqama $>h$ (Konsisten), Tawazun (Seimbang), (6) Sali>m al-Aqi>dah (Memiliki Akidah yang Benar), dan (7) $a l$-Tasa $>m u h\} \quad$ (Toleransi). ${ }^{16}$ Enam kriteria pendidikan al-Qur'an ini diambil dari potongan-potongan

\footnotetext{
${ }^{16}$ Mutmainnah, Pendidikan Akhlak dalam Perspektif al-Qur'an: Telaah Tafsir alMisbah Surah al-Furqan : 63-75, dalam
}

ayat Q.S. al-Furqan [25]: 63-75, sebagaimana berikut:

Pertama, al-Tawa $>d\} u^{\prime}$ atau rendah diri. Diambil dari ayat: "allaz $\backslash$ i> yamsyu>na 'ala> al-ard\} hawnan" (ialah orang-orang yang berjalan di atas muka bumi dengan rendah hati). Seorang pendidik harus mampu menumbuhkan sifat hawnan kepada anak didik untuk selalu rendah hati. Kedua, anak didik harus diajarkan pentingnya memiliki sifat al-'afwu atau memaafkan. Pemahaman ini diambilkan dari ayat: "wa izla> kha>t\}abu>al-ja>hilu>na $q a>l u>$ sala>man" (dan apabila orang-orang jahil menyapa mereka, mereka mengucapkan kata-kata [mengandung] keselamatan). Walaupun orang lain mengusik dan mengganggu, tetapi seharusnya seorang anak didik yang baik tetap bertutur kata yang baik dan mengandung kesalamatan. Bukan malah melawan karena itu bukan solusi penyelesaian tetapi menambah memperkeruh masalah.

Jurnal Ilmiah al-Haudl: Transformasi Pemikiran Keagamaan dan Kemasyarakatan, Volume 3, No. 5, Desember 2014. 


\section{At-Turats}

Jurnal Pemikiran Pendidikan Islam

journal homepage: http://jurnaliainpontianak.or.id/index.php/atturats

Ketiga, mengajarkan kepada anak didik agar selalu memperhatikan ibadahnya, karena baik buruk seseorang bergantung baik buruknya dalam berinteraksi dengan Allah swt. Pemahaman ini tertulis di dalam ayat: "wa allaz $\backslash$ i $>$ na yabi $>$ tu>na lirabihim sujjada>n wa qiya>ma>n (Dan mereka yang melalui malam hari dengan bersujud dan berdiri untuk Rabb mereka). Sedangka yang keempat, memiliki sifat istiqomah (kosisten), sebagaimana dalam ayat: Wa allazi $>$ na yaqu>lu>na rabbana> is rif 'anna> 'azla>ba jahannam inna 'azla>baha> ka>na gara>man innaha $>$ sa>'at mustaqara $>n$ wa $m u q a>m a>n$ (dan orang-orang yang berkata: "Ya Tuhan kami, jauhkan azab jahannam dari kami, sesungguhnya azabnya itu adalah kebinasaan yang kekal', sesungguhnya jahannam itu seburukburuk tempat menetap dan tempat kediaman). Seorang anak didik jika sudah memiliki sifat konsisten, maka bisa dipastikan juga konsisten dalam tindakan-tindakan yang bermanfaat.

Kelima, al-tawa>zun atau keseimbangan sebagaimana dalam ayat: "wa allazli>na izla> anfaqu> lam yusrifu> wa lam yaqturu> wa ka>na bayna zla>lika qawama>n" (Dan orang-orang yang apabila membelajkan, mereka tidak berlebihan, dan tidak kikir, dan adalah di tengah-tengah antara mereka yang demikian). Maksudnya di sini, seoarang pendidik tidak suka belebihlebihan karan itu tidak baik untuk dirinya sendiri dalam bergaul. Sedangkan yang keenam, Sali>m alAqi $>$ dah. Wa allaz\i> la yad'u>na ma'a Alla $>$ h ila $>$ ha $>n$ a khara wa la $>$ yaznu $>n$. (Dan orang-orang yang tidak menyembah Tuhan yang lain beserta Allah dan tidak berzina). AlQur'an tidak hanya melihat kebaikan pada dari sisi tindakan saja, tetapi juga pada akidah yang mentauhidkan Allah (Islam).

Ketujuh, al-ta>samuh\} atau toleransi, sebagaimana dalam ayat: “wa la > yaqtulu>na al-nafsa allati>y h)arrama Alla>h illa> bi al-h\}aqq" (dan tidak membunuh juwa yang diharamkan Allah kecuali dengan yang benar). Memberikan kebebesan kepada orang lain yang memiliki pandangan berbeda. Selama tidak 


\section{At-Turats}

Jurnal Pemikiran Pendidikan Islam

journal homepage: http://jurnaliainpontianak.or.id/index.php/atturats

mengganggu pada agamanya, tidak perlu membesar-besarkan masalah apalagi sampai tawuran.

Dalam penafsiran pada ayat di atas, Mutmainnah hanya melakukan deskripsi ulang pendapat Quraish Shihab dalam menafsirkan ayat tersebut di atas. Karena tulisan Mutmainnah terkesan tidak kaya dengan referensi penafsiranpenafsiran ulama tafsir lain sebagai bentuk membandingkannya, bahkan belum terlihat adanya kritikan dari pribadi Mutmainnah atas penafsiran itu.

Seharusnya Mutmainnah juga menyinggung surah al-Furqan dilihat dari aspek tata letak turunnya wahyu dan tata letak dalam mushaf. Ini penting dikemukakan karena posisi Surah al-Furqan apabila dilihat dari sistematika Mushaf Ustmani menempati posisi yang ke-25 dan dari sistematika turunnya wahyu termasuk bagian dari salah satu dari surah Makkiyah yang diapit oleh Surah Yasin dan Fathir. ${ }^{17}$ Keseluruhan ayat-

${ }^{17}$ Lihat dalam penjelasan, Wahbah alZuh\}ayli>y, Tafsi>r al-Muni>r fi> al'Aqi>dah wa al-Syari>'ah wa al-Manhaj, ayat yang terkandung di dalamnya berjumlah 77 (tujuh puluh tujuh) ayat. Sebagai ciri khasnya, Surah Makkiyah dari ayat Madaninah, adalah kandungannya lebih menekankan kepada perbaikan akidah atau penmbentukan moral yang mulia.

Adapun dilihat dari kontennya, Surah al-Furqan dari ayat 63-75 membicarakan tentang hambahamba Allah swt yang taat sehingga mereka memperoleh derajat yang tinggi di sisinya dan mendapatkan tempat surga. ${ }^{18}$ Meski ayat-ayat ini tidak secara spefisik membicarakan tentang pendidikan, tetapi lebih kepada akhlak. Namun ketika Mutmainnah membawa ini kepada ranah pendidikan tentu tidak salah karena dalam pendidikan juga harus ada akhlaknya.

Kedua, Kepribadian Muslim dalam Pandangan Psikologi Agama, ditulis oleh Irmayanti. Tulisan Irmayanti ini bisa disebut sebagai praktik semitafsir yang kajiannya upaya memadukan ilmu agama dan umum (interdisipliner). Disebut semi-tafsir karena sedikit

(Damasykus: Da>r al-Fikr, 2009), juz. 10, h. 6.

${ }^{18}$ Wahbah al-Zuh\} ayli $>$ y, Tafsi $>$ r alMuni >r.....juz. 10, h. 109. 


\section{At-Turats}

Jurnal Pemikiran Pendidikan Islam

journal homepage: http://jurnaliainpontianak.or.id/index.php/atturats

menjadikan sebagian ayat al-Qur'an sebagai penjelasannya. Kajian tafsirnya terkesan hanya sebagai kutipan, Irmayanti secara spesifik tidak menggunakan metode dan keumuman ayat-ayat yang dikutip tidak diberikan indikasi sehingga keumuman ayat masih umum.

Ketiga, Analisis Kritis Terhadap Pendayagunaan Zakat Untuk Memberantas Kemiskinan, ditulis oleh Burhanudin. Di dalam tulisan Burhanuddin ini belum bisa sepenuhnya disebut sebagai praktik tafsir karena ayat al-Qur'an hanya sebagai referensi penguat dari data penelitiannya. Bukan menjelaskan pada yang dimaksud oleh ayat tersebut walau memang terkadang ada sedikit memberikan komentar pada ayat-ayat yang dikutipnya.

Keempat, Kepemimpinan dan Manajemen dalam Organisasi Pendidikan Islam, ditulis oleh Syarafudin. Mengomentari muatan tafsir dalam karya Syarudin di atas, bahwa menurut penulis Syafrudin hanya mencari kosa kata, seperti khalifah untuk menunjukkan makna pemimpin, kata 'adl, qisth dan haqq untuk arti bersikap adil, dan lain-lain. Analisanya hanya seputar kata perkata untuk mengartikan apa-apa yang berhubungan dengan kepemimpinan. Syafrudin melakukan penafsiran tetapi tidak menggunakan metode sebagaimana dalam ilmu tafsir hanya sebatas mencari makna kosa kata saja.

\section{Kesimpulan}

Dari penelitian tersebut dapat disimpulkan bahwa muatan tafsir alQur'an dalam karya-karya dosen Perguruan Tinggi Islam di Kalimantan Barat sangat minim sekali dapat dihitung dengan jari tangan, berdasarkan statistiknya tidak paralel dengan jumlah mereka yang sangat banyak. Bahkan tingkat pemahamannya juga kurang. Hal ini dapat ditandai dengan tulisan-tulisan mereka yang lebih banyak hanya menjadikan al-Qur'an sebagai kutipan atau dikomentari sekedarnya saja. AlQur'an tidak dijadikan sebagai objek kajian utama yang dikaji dengan sedalam-dalamnya. Kutipan dan komentar tersebut tidak disertakan dengan kaidah dan corak tafsir, karena lebih banyak mengandalkan kepada pemahaman pada terjemahan ayat alQur'an.

Jika diamati secara lebih seksama dari metode penulisan tafsir, maka karya-karya yang penulis kaji hanya satu penelitian secara utuh masuk dalam ruang lingkup al-Tafsi $>r$ al- 


\section{At-Turats}

Jurnal Pemikiran Pendidikan Islam

journal homepage: http://jurnaliainpontianak.or.id/index.php/atturats

Mawd\}' 'ui>y, yaitu karya Eka Hendry dengan judul "Api dalam Islam: Konstruksi Pendidikan Damai dalam Pandangan al-Qur'an". Adapun karyakarya yang lain terdapat muatan tafsir alQur'an tetapi tidak sampai pada rekonstruksi makna. Penafsiranpenafsiran yang ada banyak tidak memperhatikan apakah ayat tersebut bagian dari ayat Makki dan Madani, tidak disertakan pula keterangan terkait konteks historinya (sabab al-nuzu>l), serta sering kali tidak mencari keserasian antar ayat-ayat (al-muna>sabah) yang dikutipnya.

Sedangkan apabila dilihat pola narasi pemikiran dalam menafsiran alQur'an, maka muatan tafsir dalam karyakarya dosen tersebut lebih banyak dengan nalar logika (al-tafsi $>r$ bi al$\left.r a^{\prime} y\right)$ dan sangat jarang sekali menggunakan (al-Tafsir bi al-Ma'sur), misalnya al-Qur'an ditafsirkan dengan al-Qur'an, atau dengan Hadis, dan atau dengan riwayat Sahabt atau Tabi'in.

Selain itu, karya-karya para dosen tersebut kebanyakan memuat tafsir interdisipliner. Artinya, banyak bidang studi yang terselip di dalam karya-karya mereka yang terkadang al-Qur'an juga sebagai penjelasannya. Turut menghiasi dalam karya mereka seperti kajian tafsir psikologi dakwah, tafsir pendidikan, tafsir ekonomi, dan lain-lain. Dalam kata lain, nuansa tafsir dari karya-karya dosen-dosen itu lebih banyak bercorak tafsir Adabi $>$ Ijtima'i $>y$, yaitu suatu penafsiran al-Qur'an yang mengacu kepada riil kehidupan atau sesuatu yang benar-benar dialami oleh masyarat sehingga bentuk tafsir ini lebih banyak menyentuh kepada psikologis.

\section{DAFTAR PUSTAKA}

Abduh, Muh\}ammad., dan Rasyi $>$ d Rid\}a>, Tafsi $>r$ al-Manar, Mesir: Da>r al-Mana>r, 1367.

Ashfa>hani>, Al-Ragi>b al-., alMufrada>t fi> Gari>b alQur' $a>n$, Beirut: Da>r alMa'rifah, t.th.

'Abd al-Muta'al al-Sa'i>di>, alMujaddidu $>n$ fi $>$ al-Isla $>m$, al-Azhar, Maktabat al-Ada $>b$, 2006.

Baidan, Nashruddin., Perkembangan Tafsir di Indonesia, Solo: Tiga Serangkai Mandiri, 2003.

Burhanuddin, Analisis Kritis Terhadap Pendayagunaan Zakat untuk Memberantas Kemiskinan, dalam Jurnal Ilmiah al-Haudl: Transformasi Pemikiran Keagamaan dan Kemasyarakatan, Volume 3, No. 5, Desember 2014.

Chirzin, Muhammad., al-Qur'an dan Ulumul Qur'an, Jakarta: Dana Bhakti Prima Yasa, 1998. 


\section{At-Turats}

Jurnal Pemikiran Pendidikan Islam

journal homepage: http://jurnaliainpontianak.or.id/index.php/atturats

Dzahabi>, Muh \}ammad H\}usain al-., al-Tafsi>r wa alMufassiru>n, Kairo: Maktabah Wahbah, 2003

$B u h\}$ utsun fi> 'Ulu>m alTafsi>r wa al-Fiqh wa alDa'wah, Kairo: Da>r alHadi>ts, 2005.

Kita>buka 'Ilmu al-Tafsi>r, al-Qa>hirah: Da>r alMa'a $>$ rif, t.th.

Farma>wi>, Abd al-H\{ayyi al-., alBida $>$ yah fi> al-Tafsi $>r$ alMawd $u>>^{\prime} i>$ : $\quad$ Dira $>$ sah Manhajiyyah Mawd\{u>iyyah, T.t.p. t.p., 1977.

Gunawan, Imam., Metode Penelitian Kualitatif: Teori dan Praktik, Jakarta: Bumi Aksara, 2013.

Gusmian, Islah., Khazanah Tafsir Indonesia: Dari Hermeneutik hingga Ideologi, Yogyakarta: LKiS, 2013.

Guba, Egon E., The Paradigm Dialog, Newbury Park: Sage, 1990.

Ghallab, Abd Kari>m., Si>rah alMadza>hib wa al-'Aqa>'id fi> al-Qur'a>n, Beirut: Dar al-Kitab al-Lubnaniyah, t.th.

Hasan, M. Iqbal., Pokok-Pokok Metodologi Penelitian dan Aplikasinya, Jakarta: Ghalia Indonesia, 2002.

Hefni, Harjani., Komunikasi Islam, Pontianak: IAIN Pontianak Press, 2014.
Hendry, Eka., Api Damai Islam:

Konstruksi Pendidikan Damai dalam Pandangan al-Qur'an, Pontianak: IAIN Pontianak Press, 2017.

'Itir, $\mathrm{Nu}>\mathrm{r}$ al-Di>n al-., 'Ulu>m alQur'a>n, al-Qa>hirah: Maktabah Wahbah, t.th.

'Ilyan, Rabhi Mustafa., al-Bahts al'Ilmi: Asasuhu, Manahijuhû wa Asalibuhu, Ijraatuhu, Jordan: Bayt al-Afkar alDawliyyah, t.th.

Irmayanti, Kepribadian Muslim dalam Pandangan Psikologis Agama, dalam Jurnal Ilmiah al-Haudl: $\quad$ Transformasi Pemikiran Keagamaan dan Kemasyarakatan, Volume 3, No. 5, Desember 2014.

Ja>biri>, Muh\}ammad A<bid al-., Madkhal Ila> al-Qur'a>n alKari $>m$, Beiru $>$ t: Markaz Dira>sa>t al-Wah $\}$ dat al'Arabiyyah, 2006.

Jaya, IKAPI DKI., Metode Penelitian Kepustakaan, Jakarta: Yayasan Obor Indonesia, 2008.

Kas \}i >r, Ibn., Tafsi >r al-Qur'a>n al'Az\i>m T.t.p.: Mu'assisah Qurtubah, t.th.

Maman, dkk., Metodologi Penelitian Agama: Teori dan Praktik, Jakarta: RaaGrafindo Persada, 2006.

Muslim, Muslt\}afa>., Maba>his\} fi> al-Tafsi>r al-Mawdu>', Damaskus: Da>r al-Qalam, 2000. 


\section{At-Turats}

Jurnal Pemikiran Pendidikan Islam

journal homepage: http://jurnaliainpontianak.or.id/index.php/atturats

Mutmainnah, Pendidikan Akhlak dalam Perspektif al-Qur'an:

Telaah Tafsir al-Misbah Surah al-Furqan : 63-75, dalam Jurnal Ilmiah al-Haudl: Transformasi Pemikiran Keagamaan dan Kemasyarakatan, Volume 3, No. 5, Desember 2014.

Mulyana, Deddy., Metodologi Penelitian Kualitatif, Bandung: PT Remaja Rosdakarya, 2003.

Mustaqim, Abdullah., Epistemologi Tafsir Kontemporer, Yogyakarta: Penerbit LKiS, 2009.

Penelitian al-Qur'an dan Tafsir, Yogyakarta: Idea Pres, 2016.

Maharani, Kumala., "Metode Penelitian

Kuantitatif/Paradigma

Penelitian Ilmu Sosial dan

Penelitian Kuntitatif",

http://word-of-

me.blogspot.co.id/2012/10/

metodepenelitiankuan-titatif-

paradigma.html, akses 21

Oktober 2018.

Miskari, Titik Temu Antara Hukum Islam dan Hukum Positif dalam Jurnal Al-Astar: AlSyari'ah dan Tarbiyah STAI Mempawah, Vol. 1. No. I, Maret 2015.

M. Subana dan Sudrajat, DasarDasar Penelitian Ilmiah, Bandung: Pustaka Setia, 2005.
Nawawi, Hadari., Metode Penelitian Bidang Sosial, Yogyakarta: Gajah Mada University press, 1999.

Nurjamilah, Cucu., Manajemen Dakwahh Masjid Berbasis Kesetaraan Gender, Pontianak: IAIN Press, 2014.

Qurasyi >, Muh \}ammad al-Jawzi> al., Za>du al-Masi $>r$ fi $>$ 'Ilmi al-Tafsi>r, T.tp.: al-Maktab al-Isla $>$ miyyah, t.th.

Qaysi>y, 'Abd al-Qa>dir 'Abd al$\mathrm{H}\{$ ami $>\mathrm{d}$ al-., The Term of Comprative Exposition The Origination, The Importance, and The Efforts of Scholars on It a Research Unsheathed From a Dissertation, Supervised by The Owner of Upgrade, Baghdad University: College of Islamic Sciences, t.th.

Qurt\}u $>$ bi>y, Ibn Jari>r al-., al$J a>m i, \quad a l-A h\rangle k a>m$ alQur'a>n wa al-Mubayyin Lima> Tad\}amanahu min alSunnah wa $A<y i$ al-Furqa $>n$ (Beiru>t: Mu'assisat alRisa>lah, 2006.

$\operatorname{Rid}\{\mathrm{a}>, \quad$ Rasyi $>$ d., $\quad$ al-Wah $\} y \quad a l-$ Muh\}ammadi>, al-Qa>hirah: Maktabat al-Qa>hirah, 1960, H.

Rippin, Andrew., "Tafsir", dalam Mircea Eliada (ed.), The Encyclopedia of Religion, New York: Simon \& Schuster Macmillan, 1995. 


\section{At-Turats}

Jurnal Pemikiran Pendidikan Islam

journal homepage: http://jurnaliainpontianak.or.id/index.php/atturats

Rasyid, Harum., Metode Penelitian Kualitatif, Pontianak: STAIN Pontianak, 2000.

$\mathrm{Ru}>\mathrm{mi}>$, Fahd bin 'Abd al-Rah \}man bin Sulayma>n al-., Buhu>sl fi> Us\}u>l al-Tafsi>r wa Mana>hijuh T.t.p.: Maktabat al-Tawbah, 1419.

Rusmalita, Santa., Psikologi Dakwah, Pontianak: IAIN Pontianak Press, 2014.

Syukur, Abdul., "Mengenal Corak Tafsir Al-Qur'an" dalam Jurnal El-Furqonia, Sekolah Tinggi Ilmu Ushuluddin (STIU), Pamekasan, Vol. 01., No. 01,Agustus 2015.

Sanaky, Hujair A.H. Metode Tafsir (Perkembangan Metode Tafsir Mengikuti Warna Atau Corak Mufassirin), Jurnal alMawarid Jurnal Hukum Islam, Universitas Islam Indonesia, Yogyakarta, Edisi Ke-XVIII, 2008.

Sabt, Kha $>$ lid bin 'Us\ma>n al-., Qawa>'id al-Tafsi>r: Jam'a $>n$ wa Dira $>$ satan, T.tp.: Da>r ibn 'Affa $>$ n, t.th.

S|ad\}ar, Muh\{ammad Ba>qir al-., alMadrasat al-Qur'a>niyyah, T.t.p.: Marka $>\mathrm{z}$ Tah\}qi>qat Kamfiyu $>$ ter 'Ulu $>$ m alIsla $>\mathrm{mi}>$, t.th.

Sadar, Muh\{ammad Ba>qir al-., alMadrasat al-Qur'a>niyyah, T.t.p.: Marka $>\mathrm{z}$ Tah\}qi>qat Kamfiyu $>$ ter 'Ulu $>$ m alIsla $>\mathrm{mi}>$, t.th.
Sa'i $>$ d, 'Abd al-Satta $>$ r Fath \} Allah., al-Madkhal ila> al-Tafsi>r al-Mawd $u>$ > $i>$, al-Qa>hirah: Da>r al-Tawzi>' wa al-Nasyri al-Isla>miyyah, 1991.

Sayyid 'Ali>, Mah\}mu $>$ d alNuqa $>$ rsyi $>$ al-., Mana $>$ hij alTafsi >r min al- 'As $\backslash$ ral-Awwal ila> al-'As\r al-H\}adi>s, Maktabah al-Nahdah, 1406.

Surakhmad, Winarno., Pengantar Penelitian Ilmiah, Bandung: Tarsito, 1985.

Syawka $>$ ni $>y, \quad \operatorname{Muh}\{\operatorname{ammad}$ bin 'Ali>y bin Muh\}ammad al-., Fath\} al-Qadi>r al-Ja>mi' Bayn Fannay al-Riwa>yah wa al-Dira $>$ yah min 'Ilmi alTafsi $>r$, Beiru>t: Da>r alMa'rifah, 2007.

Syarif, Wujud di Balik Teks: Studi alQur'an dengan Pendekatan Hikmah, Bandung: Nusa Media, 2014.

Soekanto,. Soerjono dan Sri Mamudji, Penelitian Hukum Normatif; Suatu Tinjauan Singkat, Jakarta: Raja Grafindo Persada, 2006.

Sari, Nurma., Paradigma Akuntasi Syariah, Pontianak: IAIN Pontianak Press, 2014.

T\{ aba>ri>, Imam Jari $>$ r al-., $J a>m i$ ' al-Baya $>n$ 'an Ta'wi $>l A<y i$ al-Qur'a>n, T.tp.: Da>r Hijr, 2001

Tustari>y, Imam al-., Tafsi $>r$ alQur'a>n al-'Az\i>m, alQa>hirah: Da>r al-H $\{$ aram Li Tuta>s $\{, 2004$. 


\section{At-Turats}

Jurnal Pemikiran Pendidikan Islam

journal homepage: http://jurnaliainpontianak.or.id/index.php/atturats

Yusrain, "Manajemen Stress Melalui

Bimbingan Konseling Islam" dalam Jurnal Ilmiah AlMuttaqin, Vol. IV, Desember 2016.

Yusuf, Yunan., "Karakteristik Tafsir al-Qur'an di Indonesia Abad keduapuluh", dalam Jurnal Ulumul Qur'an., Vol. III, No. 4,tahun 1992.

Zarkasyi $>, \quad$ Badr $\quad$ al-Di $>$ n Muh $\{$ ammad bin 'Abd Alla $>\mathrm{h}$ al-., al-Burha>n fi> 'Ulu>m al-Qur'a>n, Kairo: Da>r alHadi>ts, 2006.

Zarqa>ni>, Muh $\}$ ammad 'Abd al'Azhi>m al-., Mana>hil al'Irfa $>n$ fi> 'Ulu>m alQura $>n$, Kairo: Da>r alHadi>ts, 2001.

Zuh\}ayli >y, Wahbah al-., al-Tafsi $>r$ al-Muni>r fi> al-'Aqi>dah wa al-Syari>ah wa alManhaj, Damaskus: Da>r alFikr, 2009.

Zuhdi, M. Nurdin., Pasaraya Tafsir Indonesia: Dari Kontestasi Metodologi Hingga Kontekstualisasi, Yogyakarta: Kaukaba Dipantara, 2014.

Zuh \}ayli>y, Wahbah al-., Us\u>l alFiqh al-Isla>miyyah, Damaskus: Da>r al-Fikr, 1986.

Tafsi>r alMuni>r fi> al-'Aqi>dah wa al-Syari>'ah wa al-Manhaj, Damasykus: Da $>$ r al-Fikr, 2009. 